\title{
RECOGNITION OF ACOUSTIC SIGNALS OF INDUCTION MOTOR USING FFT, SMOFS-10 AND LSVM
}

\section{ROZPOZNAWANIE SYGNAŁÓW AKUSTYCZNICH SILNIKA INDUKCYJNEGO Z ZASTOSOWANIEM FFT, SMOFS-10 I LSVM*}

\begin{abstract}
A correct diagnosis of electrical circuits is very essential in industrial plants. An article deals with a recognition method of early fault detection of induction motor. The described approach is based on patterns recognition. Acoustic signals of specific induction motor are analyzed patterns. Acoustic signals include information about motor state. The analysis of the patterns was conducted for three states of induction motor using Fast Fourier Transform (FFT), shortened method of frequencies selection (SMoFS-10) and Linear Support Vector Machine (LSVM). The results of calculations suggest that the method is efficient and can be also used for diagnostic purposes.
\end{abstract}

Keywords: acoustic signal, induction motor, feature extraction, classification.

\begin{abstract}
Prawidlowa diagnostyka obwodów elektrycznych jest bardzo istotna w zaktadach przemystowych. Artykut zajmuje sie metoda rozpoznawania stanów przedawaryjnych silnika indukcyjnego. Opisane podejście jest oparte na rozpoznawaniu wzorców. Sygnaty akustyczne określonego silnika indukcyjnego sa badanymi wzorcami. Sygnaty akustyczne zawieraja informacje o stanie silnika. Analiza wzorców została przeprowadzona dla trzech stanów silnika indukcyjnego używajac FFT, skróconej metody wyboru częstotliwości (SMoFS-10) i liniowej maszyny wektorów wspierających (LSVM). Wyniki obliczeń sugeruja, że metoda jest skuteczna i może być również zastosowana dla celów diagnostycznych.
\end{abstract}

Stowa kluczowe: $\quad$ sygnat akustyczny, silnik indukcyjny, ekstrakcja cech, klasyfikacja.

\section{Introduction}

The induction motors are used in various industries such as: mining, fuel, metallurgical. These motors have low maintenance and low price. To reduce maintenance costs scientists analyze mechanical properties of materials $[18,20,25,30]$.

They also develop early fault detection methods $[1,5,6,10-15]$. Especially non-invasive methods are developed such as: acoustic, vibrations, thermal, magnetic [3, 14, 19, 27, 28, 29, 35, 36, 38]. Noninvasive methods are capable to diagnose early faults without disassembly the induction motor. Many of them used patterns recognition and signal processing to identify type of fault.

Incipient faults of motors may change into damages and may stop the production line. The stopped production line causes losses of resources and production time. It increases the cost of operation and maintenance.

This article deals with a recognition method of early faults of induction motor. Proposed method uses Fast Fourier Transform (FFT), shortened method of radio frequencies selection (SMoFS-10) and Linear Support Vector Machine (LSVM).

\section{Proposed approach of recognition of acoustic signal of induction motor}

The proposed approach of recognition of acoustic signal of induction motor contained two processes: a pattern creation process and an identification process. These processes were needed for proper recognition of acoustic signal (Fig. 1).

The first of them recorded acoustic signal of motor with the help of a sound card and a microphone [22]. Acoustic signal was converted

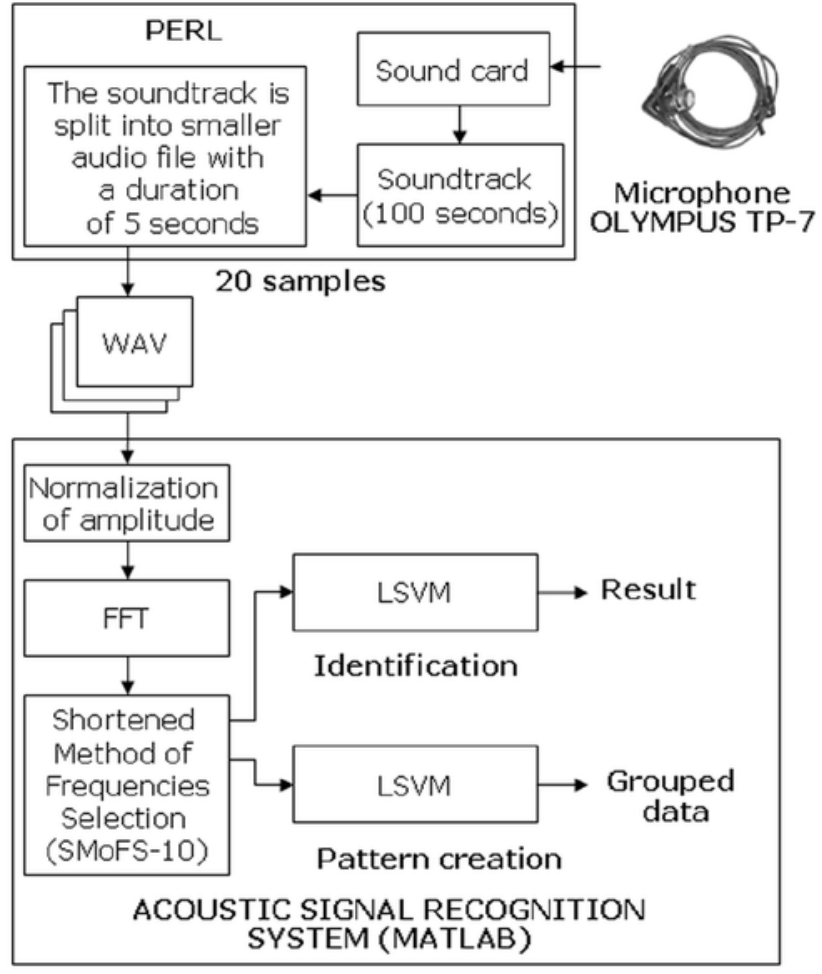

Fig. 1. Process of recognition of acoustic signal of induction motor using FFT, shortened method of frequencies selection (SMoFS-10) and Linear Support Vector Machine

$\left(^{*}\right)$ Tekst artykułu w polskiej wersji językowej dostępny w elektronicznym wydaniu kwartalnika na stronie www.ein.org.pl 
to soundtrack. Next this signal was converted into smaller audio files with a duration of 5 seconds. After that amplitudes of audio files (recorded acoustic signal) were normalized. Next the radio frequency spectra were calculated by FFT algorithm [8]. These spectra were processed by the shortened method of radio frequencies selection (SMoFS-10). The results of this method were feature vectors containing specific amplitudes of radio frequencies. The shortened method of frequencies selection (SMoFS-10) was discussed in chapter 2.2. Next step was grouping of data. For this purpose, Linear Support Vector Machine (LSVM) algorithm was used. The same methods as above were used in the identification process. Calculated feature vectors were recognized by Linear Support Vector Machine algorithm.

The described approach was based on patterns recognition. Patterns of acoustic signals of specific induction motor were analyzed. For this reason, there were two databases of patterns: training database and test database. The training database of patterns was used in the pattern creation process. All training samples and their classes were known. The test database of patterns was used in the identification process. All test samples were known, but their classes were unknown. Proposed method identified the correct class.

\subsection{Measurement and preprocessing of acoustic signals of induction motor}

The sound card and the microphone OLYMPUS TP-7 were applied to record acoustic signal of induction motor. Parameters of recorded soundtrack were following: 16-bit depth, number of channels - single channel, sampling rate $-44100 \mathrm{~Hz}$, WAVE PCM audio file. Obtained soundtrack was converted into smaller audio files with a duration of 5 seconds. Afterwards amplitudes of audio files were normalized. Normalization of amplitude divided each point of the signal by maximum value. In that way signals were comparable in the range $<-1,1>$. Next the radio frequency spectra were calculated by FFT algorithm. Obtained radio frequency spectra were used by shortened method of frequencies selection SMoFS-10.

\subsection{Shortened method of frequencies selection (SMoFS-10)}

The shortened method of frequencies selection (SMoFS-10) was based on the radio frequency spectrum. The method had following steps:

1) Calculate the difference of the radio frequency spectra of two states of motor ||$F_{1}|-| F_{2}||$, where $\left|F_{1}\right|$ - is the radio frequency spectrum of acoustic signal of the first state of motor, $\left|F_{2}\right|$ - is the radio frequency spectrum of acoustic signal of the second state of motor.

2) Select the radio frequencies, which meets following criterion:

$$
\| F_{1}|-| F_{2}||>t
$$

where $t$ - threshold of selection of amplitudes of radio frequencies (formula 1), ||$F_{1}|-| F_{2}||-$ the difference of amplitudes of radio frequencies for two different states of the motor.

Parameter $t$ should be selected properly. This parameter depends on number of analyzed states and number of selected radio frequencies. Too little number of analyzed radio frequencies can cause errors. The differences between the selected radio frequencies can have different values (for example the first difference has maximum amplitude for frequencies 100, 200, $300 \mathrm{~Hz}$; the second difference has maximum amplitude for frequencies $150,200,250 \mathrm{~Hz}$; the third difference has maximum amplitude for frequencies $150,225,275 \mathrm{~Hz}$ in that case states 1 and 3 do not have common radio frequencies). For this reason, the parameter $t$ is selected according to formulas 2 and 3 . If the number of radio frequencies (number $s$ ) is greater than 10, the method will do loop calculation (formula 3 ). If the number of radio frequencies is smaller or equal to 10 it finishes its calculations.

$$
\begin{gathered}
t=\frac{\sum_{s=1}^{s}\left\|F_{1}|-| F_{2}\right\|}{s}, \\
s \leq 10,
\end{gathered}
$$

where $t$ - threshold of selection of amplitudes of radio frequencies (it depends on $s$ and analyzed acoustic signal), $s$ - natural number, number of radio frequencies (initially $s=16384,16384$ is the number of all frequencies after usage of FFT algorithm). The amplitudes of selected radio frequencies of acoustic signals of motor are used to create feature vectors. SMoFS-10 method gives feature vector with 1-10 features, where a feature is the amplitude of radio frequency. The feature vector may have 2 features or 8 , depending on the analyzed signals and the parameter $s$ (for SMoFS-10 $s=10$ ). Optimalization of parameters $s$ and $t$ depends on the number of analyzed states, their types, disturbances and the type of machine.

Difference between spectrum of acoustic signal of faultless induction motor and spectrum of acoustic signal of induction motor with faulty rotor bar was showed in figure 2 .

Selected radio frequencies for differences between spectra of acoustic signals of induction motor were presented (Fig. 3-5). Two radio frequencies were common for analyzed states of induction mo-

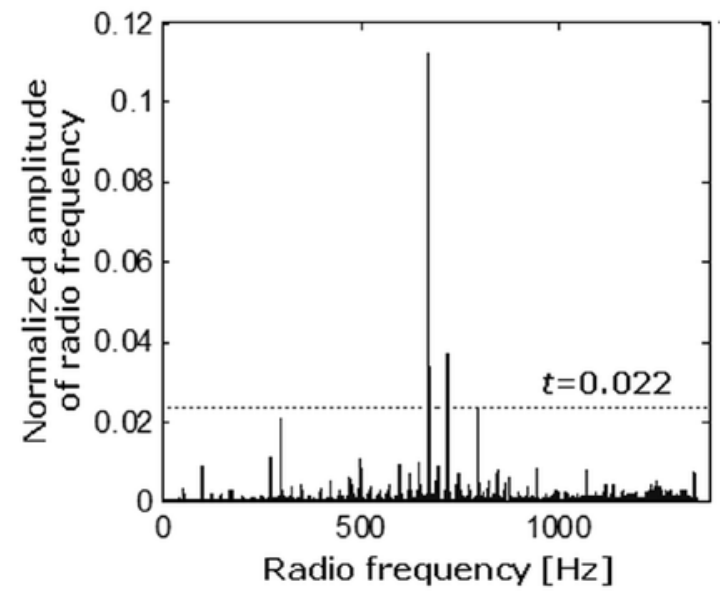

Fig. 2. Difference between spectrum of acoustic signal of faultless induction motor and spectrum of acoustic signal of induction motor with faulty rotor bar

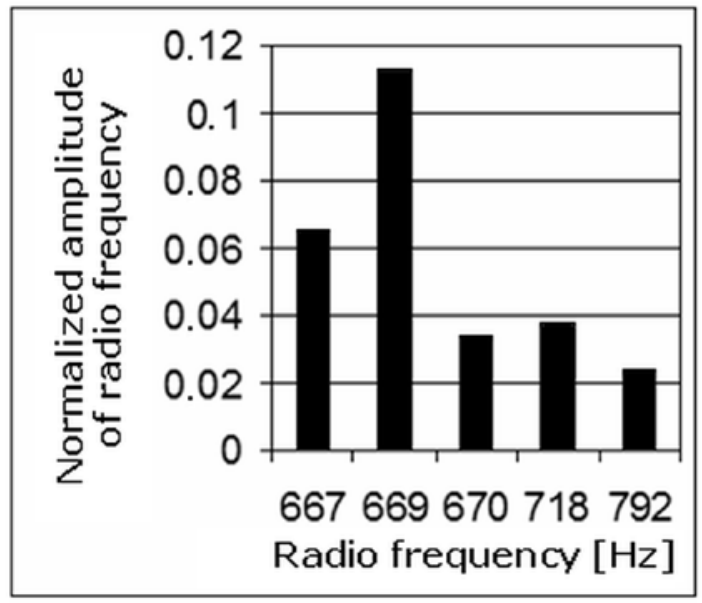

Fig. 3. Selected radio frequencies for difference between spectrum of acoustic signal of faultless induction motor and spectrum of acoustic signal of induction motor with faulty rotor bar with the use of SMoFS-10 


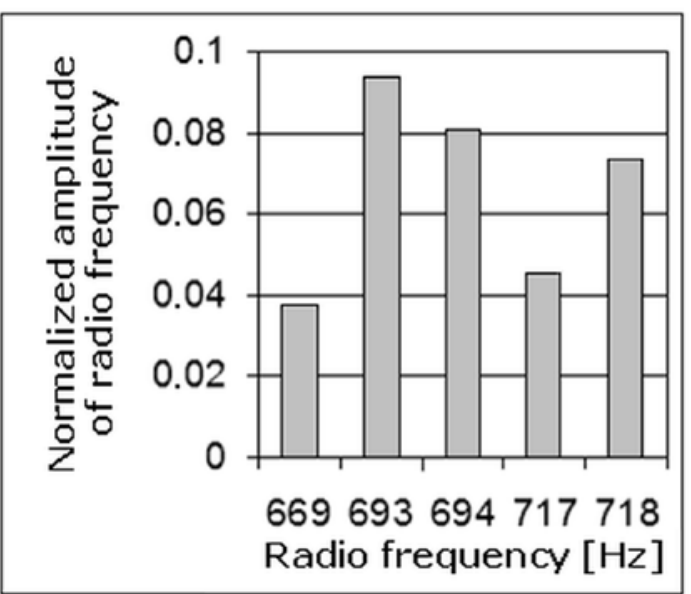

Fig. 4. Selected radio frequencies for difference between spectrum of acoustic signal of faultless induction motor and spectrum of acoustic signal of induction motor with two faulty rotor bars with the use of SMoFS-10

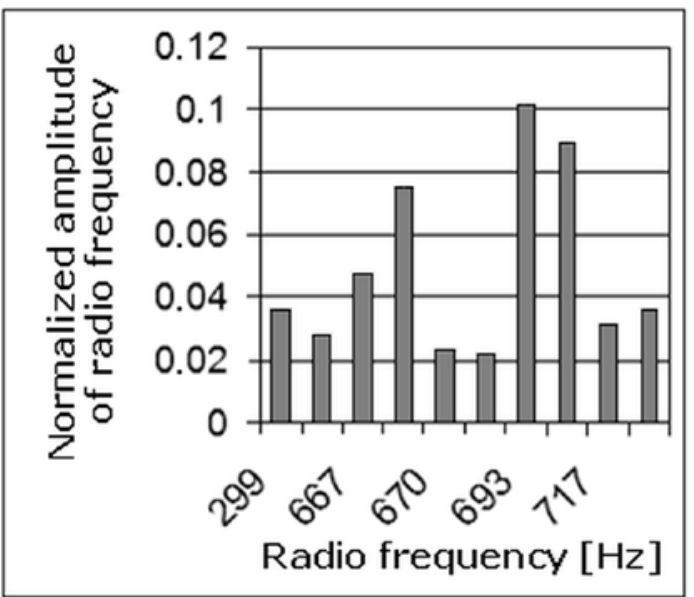

Fig. 5. Selected radio frequencies for difference between spectrum of acoustic signal of induction motor with faulty rotor bar and spectrum of acoustic signal of induction motor with two faulty rotor bars with the use of SMoFS-10

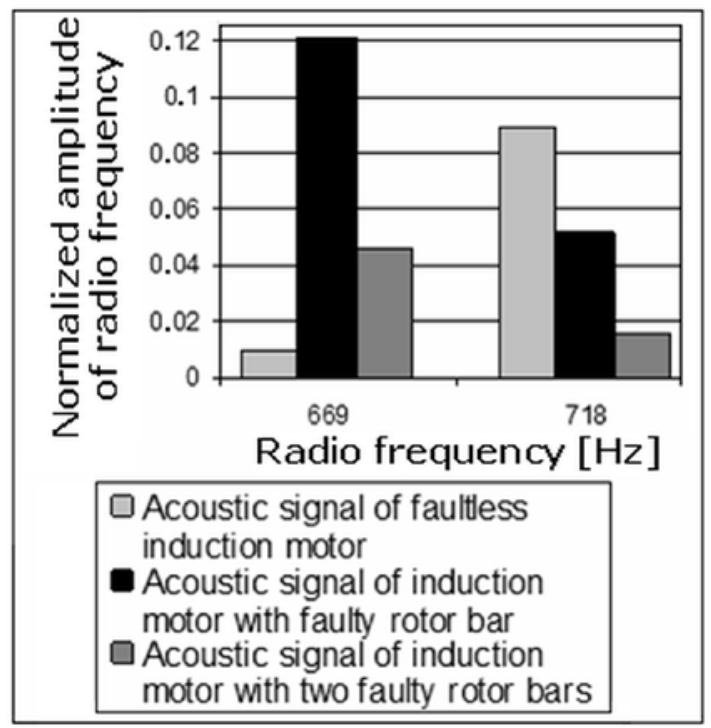

Fig. 6. Selection of common radio frequencies for 3 states of induction motor (669 and $718 \mathrm{~Hz}$ ) with the use of SMoFS-10 tor: 669 and $718 \mathrm{~Hz}$ (Fig. 6). Selected amplitudes of frequencies 669 and $718 \mathrm{~Hz}$ were used to form feature vector.

\subsection{Linear Support Vector Machine}

Last step of signal processing was classification. Scientists proposed many methods of classification in the literature $[2,4,7,9,16$, 17, 21, 23, 26, 31-34]. Linear Support Vector Machine (LSVM) classified feature vectors by finding the best hyperplane that separated all vectors of one class from those of the other class. The considered hyperplane had the largest margin between the two classes [24, 37]. There were two more hyperplanes parallel to the separating hyperplane. They cut through the closest training examples (support vectors) on either side. These hyper-planes were called "support hyperplanes". They contained support vectors. A set of vectors $\mathbf{x}_{\mathrm{i}}$ with their categories $y_{i}$ were training examples.

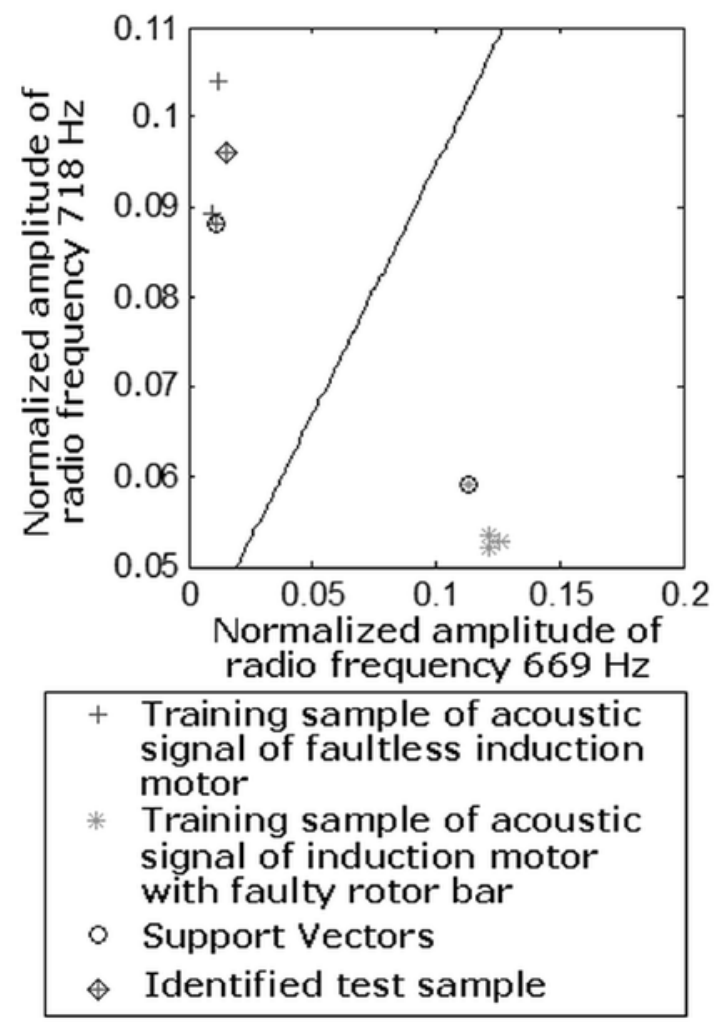

Fig. 7. Identification of test sample (acoustic signal of faultless induction motor) with the use of SMoFS-10, LSVM and training samples of acoustic signal of faultless induction motor and acoustic signal of induction motor with faulty rotor bar

A hyperplane was defined by following formula:

$$
<\mathbf{W}, \mathbf{x}>+b=0,
$$

where $\mathbf{w} \in R_{d}, \mathbf{x}_{\mathrm{i}} \in R_{d}, R_{d}$ (datapoints), $y_{i}= \pm 1,\langle\mathbf{w}, \mathbf{x}>$ was the inner product of $\mathbf{w}$ and $\mathbf{x}, b$ was real.

Solution of this problem was to find $\mathbf{w}$ and $b$ that minimize $\|\mathbf{w}\|$ for all training examples $\left(\mathbf{x}_{\mathrm{i}}, y_{\mathrm{i}}\right)$,

$$
y_{\mathrm{i}}\left(<\mathbf{w}, \mathbf{x}_{\mathrm{i}}>+b\right) \geq 1 .
$$

More about Linear Support Vector Machine could be found in literature [24, 37]. Identification of test sample of acoustic signal of faultless induction motor was showed (Fig. 7, 8). 


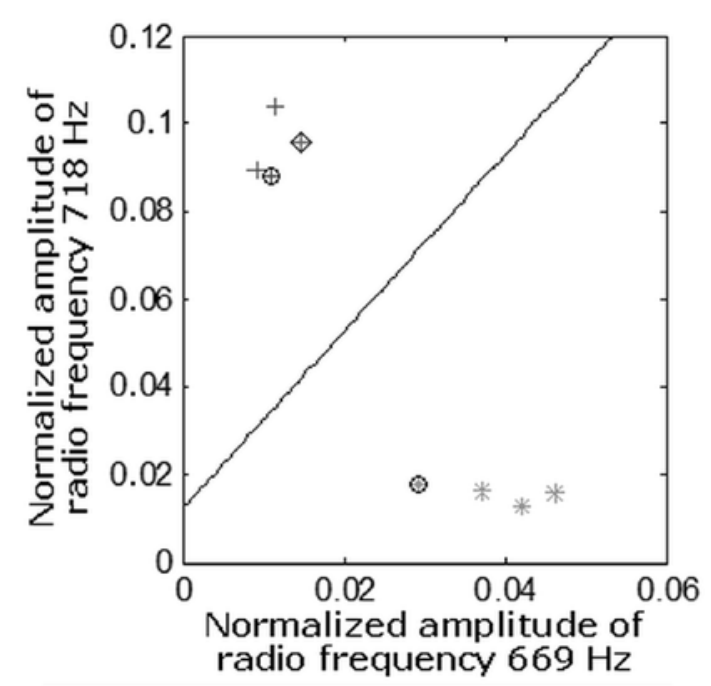

+ Training sample of acoustic signal of faultless induction motor

* Training sample of acoustic signal of induction motor with two faulty rotor bars

- Support Vectors

$\diamond$ Identified test sample

Fig. 8. Identification of test sample (acoustic signal of faultless induction motor) with the use of SMoFS-10, LSVM and training samples of acoustic signal of faultless induction motor and acoustic signal of induction motor with two faulty rotor bars

\section{Analysis of acoustic signals of three phases induction motors}

Three loaded three phases induction motors were used in analysis. These motors were the same. Open loop control system was used for these motors. Each of them had operational parameters: $U_{N}=220 / 380$ $\mathrm{V}(\Delta / \mathrm{Y}), I_{N}=2.52 / 1.47 \mathrm{~A}(\Delta / \mathrm{Y}), P_{N}=0.55 \mathrm{~kW}, n_{N}=1400 \mathrm{rpm}$, where $U_{n}$ - nominal stator voltage, $I_{n}$ - nominal stator current, $P_{N}$ - motor power, $n_{N}$ - rotor speed.

The first motor was faultless induction motor. The second motor was induction motor with faulty rotor bar. The third motor was induction motor with two faulty rotor bars (Fig. 9).

\section{Two faulty rotor bars}

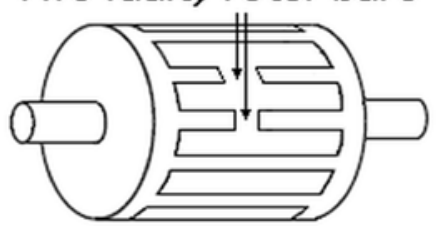

Fig. 9. Squirrel-cage rotor of three phases induction motor with two faulty rotor bars

In the pattern creation process 12 five-second training samples were processed by proposed method of acoustic signal recognition. These training samples were used to group data.
The identification process used 60 samples $(20$ samples for each class). These samples were used to evaluate efficiency of recognition of acoustic signal. This efficiency was defined as:

$$
E=\frac{\text { NoPITS }}{\text { NoTS }} 100 \%
$$

where NoPITS - number of properly identified test samples of specific class used in the identification process, NoTS - number of test samples of specific class used in the identification process, $E$ - efficiency of recognition of acoustic signal of specific class.

$$
T E o R o A S=\frac{E_{1}+E_{2}+E_{3}}{3},
$$

where TEoRoAS - Total efficiency of recognition of acoustic signal, $E_{1}$ - efficiency of recognition of acoustic signal of faultless induction motor, $E_{2}$ - efficiency of recognition of acoustic signal of induction motor with faulty rotor bar, $E_{3}$ - efficiency of recognition of acoustic signal of induction motor with two faulty rotor bars.

Table 1 presented efficiency of recognition of acoustic signal of three phases induction motor depending on state of induction motor. It also presented total efficiency of recognition of acoustic signal of induction motor.

On the basis of table 1 it can be noticed that $E$ was in the range of 90-100 \% and TEORoAS was $96.66 \%$.

Table 1. Results of recognition of acoustic signal of three phases induction motor with the use of SMoFS-10 and LSVM

\begin{tabular}{|c|c|}
\hline State of induction motor & $E[\%]$ \\
\hline Faultless motor & 100 \\
\hline Motor with faulty rotor bar & 90 \\
\hline Motor with two faulty rotor bars & 100 \\
\hline & TEoRoAS [\%] \\
\hline 3 analyzed states of motor & 96.66 \\
\hline
\end{tabular}

\section{Conclusions}

Paper presented method of recognition of acoustic signal of three phases induction motor. This method contained methods of processing such as: FFT, SMoFS-10 and LSVM. SMoFS-10 was also new method of feature extraction. Analysis of acoustic signals showed that proposed solution was good to recognize state of induction motor. Total efficiency of recognition of acoustic signal of induction motor was equal to $96.66 \%$ for 3 analyzed states of motor. Presented method can be used for early diagnostics of specific induction motors (the same size, operational parameters). It can be used for other electric motor when the patterns are properly selected. Moreover method based on acoustic signal can be used together with diagnostics methods based on thermal signals and stator current signals. In this way, it can improve the diagnostics of electrical motors.

\section{Acknowledgments}

This work has been financed under AGH researcher grant in 2015 (Adam Glowacz).

\section{References}

1. Abramov IV, Nikitin YR, Abramov AI, Sosnovich EV, Bozek P. Control and Diagnostic Model of Brushless Dc Motor. Journal of Electrical Engineering-Elektrotechnicky Casopis 2014; 65 (5): 277-282, http://dx.doi.org/10.2478/jee-2014-0044. 
2. Alshayeb M, Eisa Y, Ahmed MA. Object-Oriented Class Stability Prediction: A Comparison Between Artificial Neural Network and Support Vector Machine. Arabian Journal for Science and Engineering 2014; 39 (11): 7865-7876, http://dx.doi.org/10.1007/s13369-014-1372-4.

3. Andonova AV, Hinov NL. Thermographic Analysis of a Bridge Power Converter. Journal of Electrical Engineering-Elektrotechnicky Casopis 2014; 65 (6), 371-375.

4. Augustyniak P, Smolen M, Mikrut Z, Kantoch E. Seamless Tracing of Human Behavior Using Complementary Wearable and HouseEmbedded Sensors. Sensors 2014; 14 (5): 7831-7856, http://dx.doi.org/10.3390/s140507831.

5. Baranski M. New vibration diagnostic method of PM generators and traction motors - detecting of vibrations caused by unbalance. 2014 IEEE International Energy Conference (ENERGYCON 2014); Book Series: IEEE International Energy Conference: 28-32.

6. Baranski M, Decner A, Polak A. Selected Diagnostic Methods of Electrical Machines Operating in Industrial Conditions. IEEE Transactions on Dielectrics and Electrical Insulation 2014; 21 (5): 2047-2054, http://dx.doi.org/10.1109/TDEI.2014.004602.

7. Dudek-Dyduch E, Tadeusiewicz R, Horzyk A. Neural network adaptation process effectiveness dependent of constant training data availability. Neurocomputing 2009; 72 (13-15): 3138-3149, http://dx.doi.org/10.1016/j.neucom.2009.03.017.

8. Duspara M, Sabo K, Stoic A. Acoustic emission as tool wear monitoring. Tehnicki Vjesnik-Technical Gazette 2014; 21 (5), $1097-1101$.

9. Dzwonkowski A, Swedrowski L. Uncertainty analysis of measuring system for instantaneous power research. Metrology and Measurement Systems 2012; 19 (3): 573-582.

10. Glowacz A. Diagnostics of Synchronous Motor Based on Analysis of Acoustic Signals with the use of Line Spectral Frequencies and K-nearest Neighbor Classifier. Archives of Acoustics 2014; 39 (2): 189-194.

11. Glowacz A. Diagnostics of DC and Induction Motors Based on the Analysis of Acoustic Signals. Measurement Science Review 2014; 14 (5): 257-262, http://dx.doi.org/10.2478/msr-2014-0035.

12. Glowacz A, Glowacz Z. Diagnostics of DC machine based on analysis of acoustic signals with application of MFCC and classifier based on words. Archives of Metallurgy and Materials 2012; 57 (1): 179-183, http://dx.doi.org/10.2478/v10172-012-0007-6.

13. Glowacz A, Glowacz Z. Diagnostics of induction motor based on analysis of acoustic signals with application of FFT and classifier based on words. Archives of Metallurgy and Materials 2010; 55 (3): 707-712.

14. Glowacz A, Glowacz A, Korohoda P. Recognition of Monochrome Thermal Images of Synchronous Motor with the Application of Binarization and Nearest Mean Classifier. Archives of Metallurgy and Materials 2014; 59 (1): 31-34, http://dx.doi.org/10.2478/amm2014-0005.

15. Glowacz Z, Kozik J. Detection of synchronous motor inter-turn faults based on spectral analysis of park's vector. Archives of Metallurgy and Materials 2013; 58 (1): 19-23, http://dx.doi.org/10.2478/v10172-012-0144-y.

16. Hachaj T, Ogiela MR. Application of neural networks in detection of abnormal brain perfusion regions. Neurocomputing 2013 ; 122 (Special Issue): 33-42, http://dx.doi.org/10.1016/j.neucom.2013.04.030.

17. Jun S, Kochan O. Investigations of Thermocouple Drift Irregularity Impact on Error of their Inhomogeneity Correction. Measurement Science Review 2014; 14 (1): 29-34.

18. Krolczyk GM, Nieslony P, Legutko S. Determination of tool life and research wear during duplex stainless steel turning. Archives of Civil and Mechanical Engineering 2015; 15 (2): 347-354, http://dx.doi.org/10.1016/j.acme.2014.05.001.

19. Krolczyk GM, Krolczyk JB, Legutko S, Hunjet A. Effect of the disc processing technology on the vibration level of the chipper during operations. Tehnicki Vjesnik-Technical Gazette 2014; 21 (2), 447-450.

20. Krolczyk JB. An attempt to predict quality changes in a ten-component granular system. Tehnicki Vjesnik-Technical Gazette 2014; 21 (2), 255-261.

21. Kundegorski M, Jackson PJB, Ziolko B. Two-Microphone Dereverberation for Automatic Speech Recognition of Polish. Archives of Acoustics 2014; 39 (3): 411-420.

22. Kulka Z. Advances in Digitization of Microphones and Loudspeakers. Archives of Acoustics 2011; 36 (2): 419-436, http://dx.doi.org/10.2478/ v10168-011-0030-z.

23. Mahmood A, Alsulaiman M, Muhammad G. Automatic Speaker Recognition Using Multi-Directional Local Features (MDLF). Arabian Journal for Science and Engineering 2014; 39 (5): 3799-3811, http://dx.doi.org/10.1007/s13369-014-1048-0.

24. MathWorks - MATLAB and SimuLink for Technical Computing 2015; www.mathworks.com.

25. Nadolny K, Kaplonek W. Analysis of Flatness Deviations for Austenitic Stainless Steel Workpieces after Efficient Surface Machining. Measurement Science Review 2014; 14 (4), 204-212, http://dx.doi.org/10.2478/msr-2014-0028.

26. Nafisi H, Abedi M, Gharehpetian GB. Locating Pd in Transformers through Detailed Model and Neural Networks. Journal of Electrical Engineering-Elektrotechnicky Casopis 2014; 65 (2), 75-82, http://dx.doi.org/10.2478/jee-2014-0011.

27. Paydarnia H, Hajiaghasi S, Abbaszadeh K. Improved Structure of PNN Using PCA in Transformer Fault Diagnostic. Arabian Journal for Science and Engineering 2014; 39 (6): 4845-4851, http://dx.doi.org/10.1007/s13369-014-1004-z.

28. Pleban D. Definition and Measure of the Sound Quality of the Machine. Archives of Acoustics 2014; 39 (1): 17-23.

29. Rusinski E, Moczko P, Odyjas P, Pietrusiak D. Investigation of vibrations of a main centrifugal fan used in mine ventilation. Archives of Civil and Mechanical Engineering 2014; 14 (4), 569-579, http://dx.doi.org/10.1016/j.acme.2014.04.003.

30. Stepien K. Research on a surface texture analysis by digital signal processing methods. Tehnicki Vjesnik-Technical Gazette 2014; 21 (3): 485-493.

31. Swedrowski L, Duzinkiewicz K, Grochowski M, Rutkowski T. Use of neural networks in diagnostics of rolling-element bearing of the induction motor. Smart Diagnostics V 2014; Book Series: Key Engineering Materials; 588: 333-342.

32. Turchenko I, Kochan V, Sachenko A, Kochan R, Stepanenko A, Daponte P, Grimaldi D. Simulation modeling of neural-based method of multi-sensor output signal recognition. 2006 IEEE Instrumentation and Measurement Technology Conference Proceedings; Vols 1-5: 15301535, http://dx.doi.org/10.1109/IMTC.2006.328653.

33. Valis D, Zak L, Pokora O. Contribution to system failure occurrence prediction and to system remaining useful life estimation based on oil field data. Proceedings of the Institution of Mechanical Engineers Part O-Journal of Risk and Reliability 2015; 229 (1): 36-45, http://dx.doi. org/10.1177/1748006X14547789.

34. Valis D, Pietrucha-Urbanik K. Utilization of diffusion processes and fuzzy logic for vulnerability assessment. Eksploatacja i Niezawodnosc- 
Maintenance and Reliability 2014; 16 (1): 48-55.

35. Umasankar L, Kalaiarasi N. Internal Fault Identification and Classification of Transformer with the Aid of Radial Basis Neural Network (RBNN). Arabian Journal for Science and Engineering 2014; 39 (6): 4865-4873, http://dx.doi.org/10.1007/s13369-014-1030-x.

36. Wu RC, Tsai JI, Chiang CT, Ouyang CS. Detection of induction motor operation condition by acoustic signal. 8th IEEE International Conference on Industrial Informatics (INDIN) 2010: 792-797, http://dx.doi.org/10.1109/indin.2010.5549641.

37. Zhang DZ, Xia BK. Soft Measurement of Water Content in Oil-Water Two-Phase Flow Based on RS-SVM Classifier and GA-NN Predictor. Measurement Science Review 2014; 14 (4), 219-226, http://dx.doi.org/10.2478/msr-2014-0030.

38. Zhao Z, Wang C, Zhang YG, Sun Y. Latest progress of fault detection and localization in complex Electrical Engineering. Journal of Electrical Engineering-Elektrotechnicky Casopis 2014; 65 (1): 55-59, http://dx.doi.org/10.2478/jee-2014-0008.

\section{Adam GLOWACZ}

AGH University of Science and Technology Faculty of Electrical Engineering, Automatics Computer Science and Biomedical Engineering Department of Automatics and Biomedical Engineering al. A. Mickiewicza 30, 30-059 Kraków, Poland e-mail: adglow@agh.edu.pl 